\title{
A Comparative Study of Water Turbidity Removal Efficiency of Anthracite and Gravel in Roughing Filter
}

\author{
Bhesh Kumar Karki ${ }^{* 1}$ and Iswar Man Amatya ${ }^{1}$ \\ ${ }^{1}$ Department of Civil Engineering, Pulchowk Campus, Institute of Engineering, \\ Tribhuvan University, Kathmandu, Nepal \\ "Corresponding Email: erbhesh@gmail.com
}

\begin{abstract}
This research was carried out to compare turbidity removal efficiency of anthracite up flow roughing filter (RF) model to gravel RF model at different flow rates. Two identical filter columns with $(230 * 230 * 1570) \mathrm{mm}^{3}$ in internal dimensions were operated at same time. Same grain size $(2-4.75)$ and (4.75 - 9.5) $\mathrm{mm}$ were used in gravel model and anthracite model. All the sizes were achieved by properly sieving through standard sieve sizes $(2,4.75,9.5,12.5$ and $25 \mathrm{~mm})$. The study involved measuring turbidity every 2 hours and head loss once a day. Filter models were operated around 200 NTU influent turbidity until maximum allowable head loss was reached. Three sets of experiments were carried at filtration rate of .0 .5 to $1.5 \mathrm{~m} / \mathrm{h}$. Anthracite model was $2.07 \%$ more efficient in terms of turbidity removal. Increasing filtration rate from 0.5 to $1.5 \mathrm{~m} / \mathrm{h}$, the effluent turbidity in gravel model increased from 24.44 to $33.52 \mathrm{NTU}$ whereas that in anthracite model increased from 21.48 to $28.02 \mathrm{NTU}$ and removal efficiency in anthracite model decreased from 89 to $86 \%$ while in gravel model decreased from 88 to $84 \%$. Thus, it can be concluded that anthracite model was highly significant to removal turbidity and less affected by the flow rate change in case of efficiency. Thus, this cost-effective method can be used in context of Nepal as well.
\end{abstract}

Keywords: Anthracite and Gravel; Efficiency; Roughing filter; Turbidity

\section{INTRODUCTION}

Turbidity removal has been identified as the major problem in community water supply schemes where different water sources such as ground water, streams or river are used as a source of supply. Furthermore, growing deforestation in most of the catchments has amplified the landslides and soil erosion like disaster tremendously, thereby causing highly turbid water flow in streams and rivers. Some of the study has suggested that the treated water turbidity should be less than 0.1 NTU prior to 
chlorination [13]. High residual turbidity in the treated water would promote the re-growth of pathogens in the distribution system. Nepal Drinking Water Quality Standards (NDWQS) fixes the range of turbidity within 5 NTU in normal condition and 10 NTU when other sources are not available [10]. Depending on the sources of water the various impurities can be classified as suspended, colloidal and dissolved impurities depending on their characteristics. Mostly, the major problems in various water sources are high suspended solids, high turbidity, coliforms bacteria, agricultural runoff [10]. Aesthetically and chemically, higher turbidity is one of the major impurities present in surface water.

Roughing filtration (RF) has been identified as one of the most probable systems for the pre-treatment of water. Similar kind of study related to RF technique has shown that it is one of the most effective and reliable technique for removing suspended solids, turbidity and coliform bacteria [8, 11]. RF delivers superior treatment to plain sedimentation methods for suspensions with particulates that do not freely settle and denotes an attractive alternative to more costly conventional coagulation methods [9]. RF is primarily used to separate the water from the fine solids that are only partly retained, or not at all, by stilling basins or sedimentation tanks. The " $1 / 3-2 / 3$ " filter theory as defined by Wegelin $(1986,1996)$ is a fundamental theory for RF. By logic and experience, a particle in water can evade a sand grain either on the left or on the right or settle on its surface. Hence the possibility to fall on the grain (success of removal) is $1 / 3$ and $2 / 3$ chance of failure of removal [6]. Sedimentation take place when the unit weight of particle is greater than that of water and it's settling velocity causes the particle to deviate from the flow path and settle onto the media surface.

Filtration of water using granulated material like sand is commonly applied water treatment process. Other frequently, used granular media for water filtration consists of anthracite coal, sand and limonite [5]. Similarly, some other studies performed using different types of media such as ceramic media, gravel and Charcoal, plastic filter media has also been performed [8, 14 and 11]. According to R.C. Joshi, (2017) [12], top layer of media if replaced with anthracite have been shown of performing better than that of gravel media alone in other filters. Low uniformity coefficient of anthracite naturally yields consistent improvements in turbidity removal, due in part to more efficient solids loading. Low uniformity coefficient of anthracite chips also produces smaller changes in effluent turbidity during periods of peak influent turbidity. This awakened a strong interest in studying the performance of anthracite media on RF and to see how much variation in turbidity removal it makes in comparison to gravel media.

\section{OBJECTIVES}

The general objective of this study was to study the turbidity removal efficiency of anthracite media. Furthermore, the removal efficiency was also compared for anthracite and gravel media for varying flow rates. 


\section{MATERIAL AND METHODS}

\subsection{BENCH SCALE EXPERIMENTAL SETUP}

Two identical RF model were constructed using fibre glass material having internal dimensions of $230 \mathrm{~mm} \times 230 \mathrm{~mm} \times 1570 \mathrm{~mm}$. The laboratory models consist of clear water tank of 1000 litre capacity and a mixing tank (constant head tank) of 200 litre capacity. Raw turbid water flows from clear water tank to mixing tank through $20 \mathrm{~mm}$ diameter pipe. After sustaining constant head, the water passes through the inlet of both models established with appropriate ball valves and sampling ports. Schematic diagram of filter models is presented in Figure 1, Figure 2, Figure 3 and Figure 4, respectively.
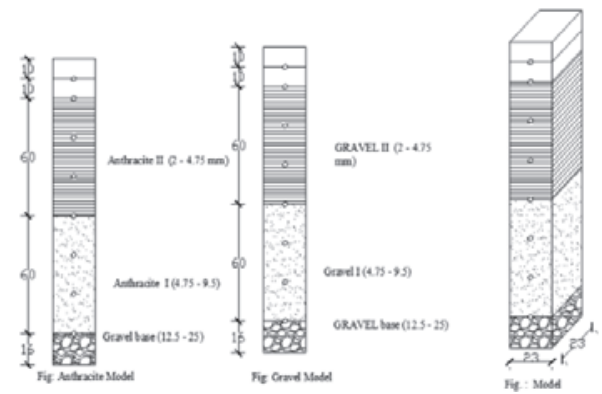

Figure 1: Schematic diagram of filter model setup

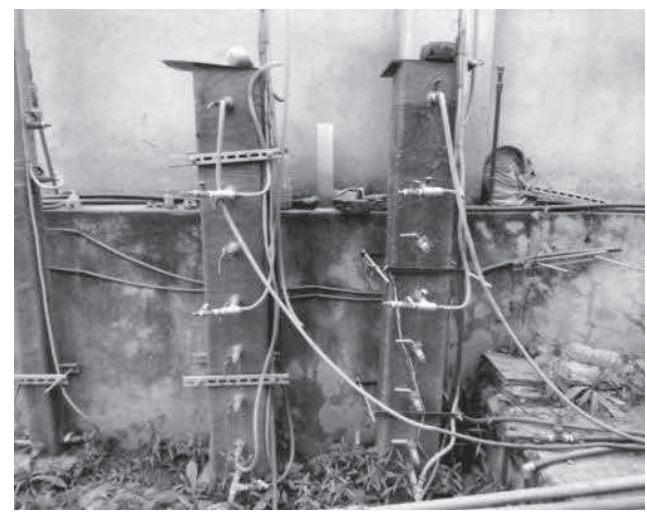

Figure 3: Filter column

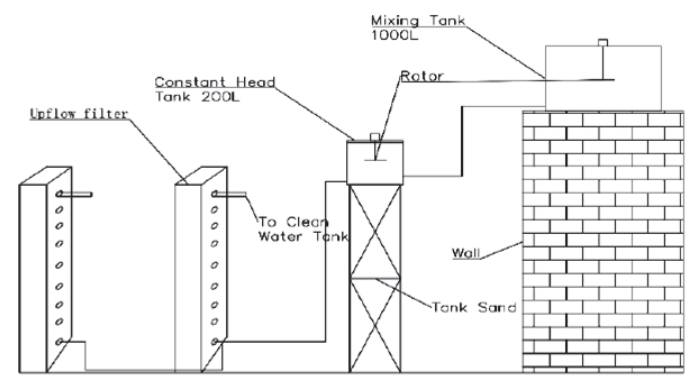

Figure 2: Schematic diagram of filter model setup

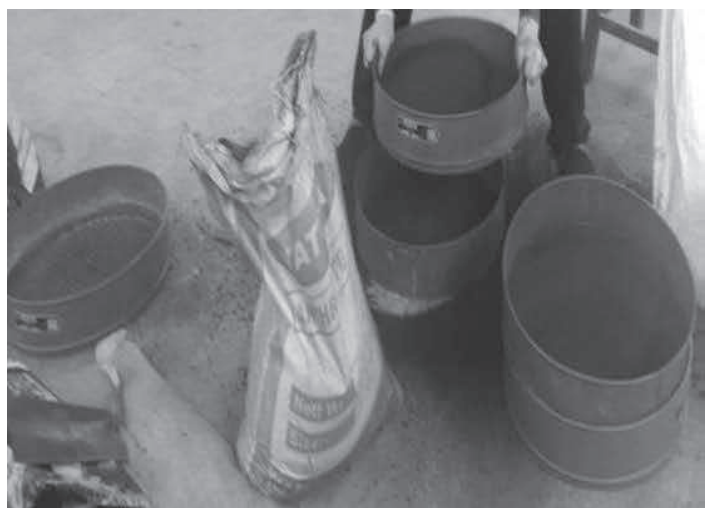

Figure 4: Sieving of anthracite coal

The detail of different media used in model was shown in Table 1. Filter media for this study had size between 9.5- and $2 \mathrm{~mm}$ diameter and required size was obtained by properly sieving. Both media were washed three times for removing mud and other organics attached with the media. All the sizes were achieved by properly sieving through standard sieve sizes $(2,4.75,9.5,12.5$ and $25 \mathrm{~mm})$. Thus, the base material aggregates used were of size ranging from $12.5-25 \mathrm{~mm}$ of $16 \mathrm{~cm}$ depth. Filter media used in 
gravel model consist of $2-4.75$ and 4.75 - $9.5 \mathrm{~mm}$ diameter gravel and that was used in anthracite model consists of 2 - 4.75 and $4.75-9.5 \mathrm{~mm}$ anthracite chips. Gate valves of $20 \mathrm{~mm}$ diameter were used before the inlet zone in both models to control flow. There were 6 no of sampling ports on both models excluding outlet ports placed $20 \mathrm{~cm} \mathrm{c} / \mathrm{c}$ in vertical direction and operated using $20 \mathrm{~mm}$ ball valves. Piezometer was connected in both models at separation of each layer of media to measure head loss occurred during operation. First sampling port was placed $16 \mathrm{~cm}$ above the base of filter and all others were placed at interval of $20 \mathrm{~cm} .10 \mathrm{~cm}$ of clear water level was maintained in the RF and outlet was placed $10 \mathrm{~cm}$ above upper media.

Table 1: Different media used in model

\begin{tabular}{|c|l|c|c|}
\hline S.No. & \multicolumn{1}{|c|}{ Category } & Filter media size $(\mathrm{mm})$ & Filter media depth $(\mathrm{mm})$ \\
\hline 1 & Media I & $4.75-9.5$ & 600 \\
\hline 2 & Media II & $2-4.75$ & 600 \\
\hline 3 & Base material & $12.5-25$ & 160 \\
\hline
\end{tabular}

\subsection{OPERATION AND TEST PROCEDURE}

The filtration rate was kept constant during each cycle which was obtained from the outlet discharge and the flow area. Operating in high rate causes poor effluent quality as well as a risk of turbidity breakthrough whereas low filtration rate increases the cost of production. Uniform turbidity of around 200 NTU was tried to maintain throughout the experiment, however it was difficult manually to do so. Hence a range from $150 \mathrm{NTU}$ to $250 \mathrm{NTU}$ was maintained to ensure uniformity throughout the experiment. Two sets of the experiment were done at the rate $0.5 \mathrm{~m} / \mathrm{h}$ for ground water and $1 \mathrm{~m} / \mathrm{h}$ for artificial turbid water. In order to obtain desired rate, flow rate from constant head is controlled from gate valve and same rate is maintained on both the models using measuring cylinder and stopwatch.

Three sets of the experiment were done at the rate $0.5 \mathrm{~m} / \mathrm{h}, 1 \mathrm{~m} / \mathrm{h}$ and $1.5 \mathrm{~m} / \mathrm{h}$ for artificial turbid water. During the first run, both models were operated at $0.5 \mathrm{~m} / \mathrm{h}$ flow rate and made to flow with natural ground water from tube well. Data were taken initially twice a day and consistency was maintained. After first cycle, prepared turbid water was made to run on both models at same flow rate of $1.0 \mathrm{~m} / \mathrm{h}$ and sampling was done every two hours. Sampling was done only after 15 seconds, to pass away accumulated solids at nozzle. Valves were opened slowly and drop wise sampling was done so as not to disturb the flow. The samples were collected in $100 \mathrm{ml}$ bottles. Bottles were appropriately numbered, and sampling was done from both models at same time to maintain the same condition. Nephelometric turbidity meter manufactured by Lutron Electronic Enterprise Co. Ltd. was used for the study. Section 2130 B, Standard Methods [1] was followed while measuring turbidity.

\subsection{ANALYTICAL METHOD}

$$
\text { Removal efficiency }(\%)=\frac{C 0-C}{C 0} \times 100 \%
$$

Where, $\mathrm{C}_{0}=$ initial turbidity concentration and $\mathrm{C}=$ Final turbidity concentration after filtration. 


\section{RESULTS:}

\subsection{EFFLUENT CHARACTERISTICS AT DIFFERENT FLOWS}

Three filter runs with loading of $0.5 \mathrm{~m} / \mathrm{h}, 1 \mathrm{~m} / \mathrm{h}$ and $1.5 \mathrm{~m} / \mathrm{h}$ for artificial turbid water were accompanied. The regression analysis, influent and effluent turbidity obtained by both filters at these flow rates are shown in Figure 4 (a), (b) and (c). From the results, it can be observed that the effluent turbidity was decreased with increase in filter run hours. Comparing the outlet turbidity from both models at various flow rates from $0.5 \mathrm{~m} / \mathrm{h}$ to $1.5 \mathrm{~m} / \mathrm{h}$, the effluent turbidity from the outlet port was reduced in every flow rates from the model that had anthracite as filter media than that with gravels. At $0.5 \mathrm{~m} / \mathrm{h}$ filter operation, the effluent turbidity was reduced by $67.5 \%$ in anthracite model and $60.8 \%$ in the gravel model as shown in Figure 3 (a). Similarly, at $1.5 \mathrm{~m} / \mathrm{h}$ filter operation, the effluent turbidity decreased by $75.69 \%$ in gravel model whereas it decreased by $75.47 \%$ in the anthracite model as shown in Figure 3 (c). With increasing flow rate, although the filtrate quantity was increased but there was decline in removal of turbidity by both filters, however running both model at high filtration rate causes early clogging which eventually affected the frequency of cleaning the media.

The regression analysis performed for different filter run time at $0.5 \mathrm{~m} / \mathrm{h}, 1 \mathrm{~m} / \mathrm{h}$ and $1.5 \mathrm{~m} / \mathrm{h}$ were analyzed. Which showed that anthracite model statistically significant $(p<0.5)$ observed by higher $\mathrm{R}^{2}$ (0.941, 0.76 and 0.94$)$, respectively.

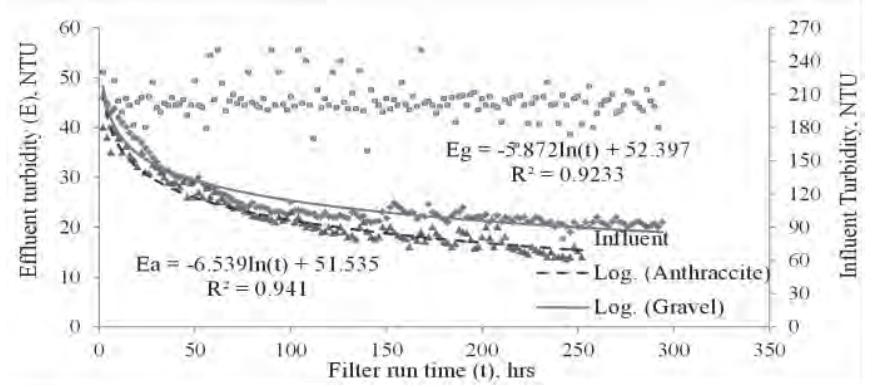

(a) Turbidity Vs. Filter run time for synthetic water at $0.5 \mathrm{~m} / \mathrm{h}$

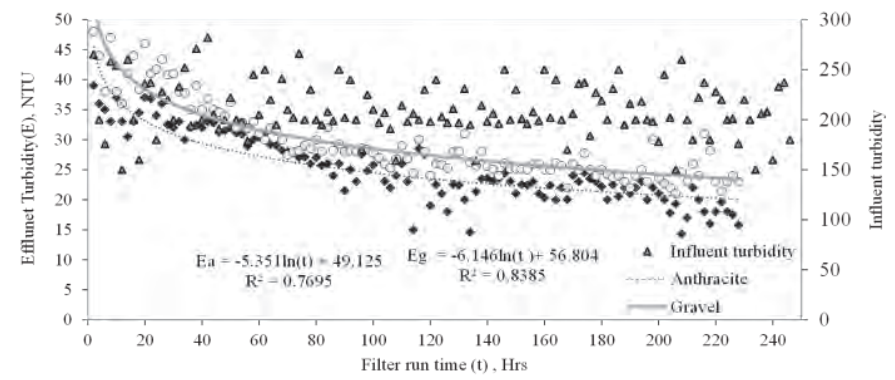

(b) Turbidity Vs. Filter run time for synthetic water at $1 \mathrm{~m} / \mathrm{h}$ 


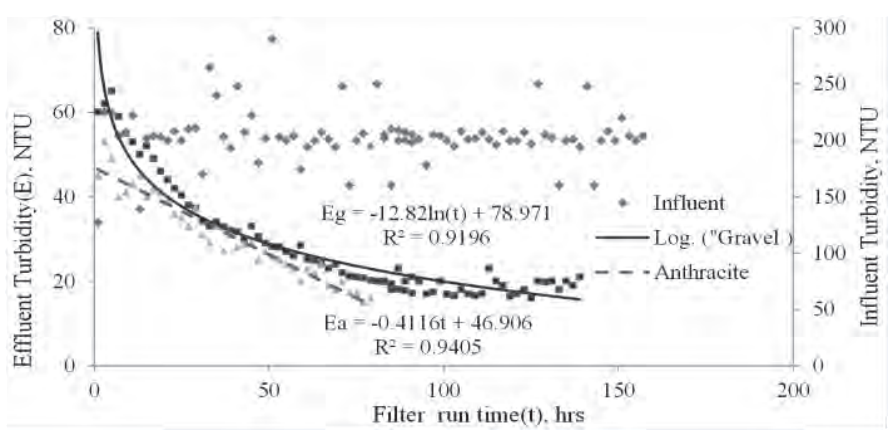

(c) Turbidity Vs. Filter run time for synthetic water at $1.5 \mathrm{~m} / \mathrm{h}$

Figure 4: Turbidity vs. Filter run time for different flow rates

While increasing the filtration rate from 0.5 to $1.5 \mathrm{~m} / \mathrm{h}$ separately in different phases of filter run, removal efficiency in anthracite model decreased from 89 to $86 \%$ while in gravel model decreased from 88 to 84 $\%$. For a given head loss, it was observed that efficiency of the filter depended on influent turbidity and hydraulic flow rate. The time of termination of filter run was decided on the basis of terminal head loss surpassing certain specified maximum head loss (Kansakar, 2018). Filter run hour was decreased with increase in the flow rate. In all the repetitions, with changing flow rate, the gravel filter exceeded the termination time of anthracite filter. In whole experiment, Anthracite model surpassed the gravel model by about 2.07 percentages in terms of turbidity removal i.e. 4.19 NTU.

Optimum filtration rate is that rate which results in maximum volume of filtrate per unit filter area while achieving acceptable quality of effluent turbidity. While increasing filtration rate from 0.5 to $1.5 \mathrm{~m} / \mathrm{h}$, the effluent turbidity in gravel model increased from 24.44 to 33.52 NTU whereas that in anthracite model increased from 21.48 to 28.02 NTU in average. RF is used as pretreatment unit before slow sand filter for which the permissible turbidity is about $30 \mathrm{NTU}$, anthracite model can be operated up to 1.5 $\mathrm{m} / \mathrm{h}$ whereas gravel mode can be operated up to $1 \mathrm{~m} / \mathrm{h}$ for influent turbidity around $200 \mathrm{NTU}$.

Depth of filter media required to reduce turbidity to desired level is directly proportional to the filtration rate. A full length of $120 \mathrm{~cm}$ of media reduced 200 NTU influent turbidity to 21.48 and $24.44,25.27$ and 28.95 and 28.02 and $33.52 \mathrm{NTU}$ in average at outlet in anthracite and gravel model at $0.5,1$ and $1.5 \mathrm{~m} / \mathrm{h}$ respectively. it has been concluded that Anthracite model was more significant compared to gravel model by about 2.07 percentages in terms of turbidity removal i.e. 4.19 NTU. Turbidity removal efficiency decreases with increase in filtration rate. While increasing the filtration rate from 0.5 to $1.5 \mathrm{~m} / \mathrm{h}$ separately in different phases of filter run, removal efficiency in anthracite model decreased from 89 to $86 \%$ while in gravel model decreased from 88 to $84 \%$. With constant influent turbidity, effluent turbidity increases with increase in filtration rate. While increasing filtration rate from 0.5 to $1.5 \mathrm{~m} / \mathrm{h}$, the effluent turbidity in gravel model increased from 24.44 to 33.52 NTU whereas that in anthracite model increased from 21.48 to 28.02 NTU. As the roughing filter is used as pretreatment unit before slow sand filter for which the permissible turbidity is about $30 \mathrm{NTU}$, anthracite model can be operated up to $1.5 \mathrm{~m} / \mathrm{h}$ whereas gravel mode can be operated up to $1 \mathrm{~m} / \mathrm{h}$ for influent turbidity around 200 NTU. 


\section{DISCUSSION}

From the above result, the removal efficiency of anthracite model was higher compared to gravel model at different flow rate of $0.5 \mathrm{~m} / \mathrm{h}$ and $1.5 \mathrm{~m} / \mathrm{h}$. The low filtration rate implies longer detention time of water within the media layer eventually leading to the better removal efficiency. However, in later cases higher removal efficiency was achieved due to maturation of filter bed thereby leading to higher turbidity removal [2]. The anthracite model was significant to remove turbidity compared to gravel model due to fact that that the media shape was significant for sedimentation, absorption and adsorption of suspended solids (SS) pollutant removal causing turbidity was significantly removed by anthracite [11]. In addition, the higher specific area and porosity than gravel also lead to the higher removal efficiency. For the identical media depth, the removal efficiency of anthracite was decreased from 89 to $86 \%$ thereby increasing filtration rate 0.5 to $1.5 \mathrm{~m} / \mathrm{h}$, range is lower compared to gravel media. Thus, the effect of change in filtration rate was less significant in anthracite model compared to the gravel model. Furthermore, some other studies also observed similar type of result decrement was within the range [2, $11,14$ and 8$]$.

\section{CONCLUSION}

This research was aimed to perform relative study of RF using sand and anthracite to determine the effectiveness of anthracite and gravel media in turbidity removal and its comparison during different filtration rate. From the result and discussion, Anthracite model was more significant compared to gravel model. In addition, the turbidity removal efficiency of RF was decreased thereby increasing filtration rate whereas with constant influent turbidity, effluent turbidity was increase with increase in filtration rate. Thus, anthracite model and gravel model can be operated efficiently at $1.5 \mathrm{~m} / \mathrm{h}$ and $1 \mathrm{~m} / \mathrm{h}$, respectively. For economical use, Anthracite model can be operated up to $1 \mathrm{~m} / \mathrm{h}$. Finally, it can be concluded that in context of Nepal, this technique can be highly applicable as a pretreatment to treat highly turbid water from small streams and river.

\section{ACKNOWLEDGMENT}

The authors are thankful to Department of Civil Engineering, Faculty of M. Sc. in Environmental Engineering program, Pulchowk campus for the laboratory and space for the conduction of research and valuable support.

\section{REFERENCES}

[1] American Public Health Association, American Water Works Association, Water Pollution Control Federation and Water Environment Federation, "Standard methods for the examination of water and wastewater". in American Public Health Association., 1920, 2310 B, pp.126.

[2] C.N. Mushila, G.M. Ochieng, F.A.O. Otieno, S.M. Shitote and C.W. Sitters. "Hydraulic design to optimize the treatment capacity of Multi-Stage Filtration units". Physics and Chemistry of the Earth, Parts A/B/C, 2016, 92, 85-91. 
[3] E. Lin, D. Page, P. Pavelic, P. Dillon, S. McClure and J. Hutson, "Evaluation of Roughing Filtration for Pre- Treatment of Stormwater prior to Aquifer Storage and Recovery",CSIRO Land and Water Science Report 03/06, 2006, pp.7, 11, 14.

[4] E.G. Pinheiro, G. Wagner (2001), "Upgrading Water Treatment Plants", in CRC Press London, 2001.

[5] E. Soyer, O. Akgiray, N.O. Eldem and A.M. Saatc 2010, "Crushed recycled glass as a filter medium and comparison with silica sand", in CLEAN-Soil, Air, Water, 2010, pp. 38(10), pp. 927

[6] G.M. Ochieng, F. A. O. Oteino (2006). "Verification of Wegelin's design criteria for horizontal flow roughing filters (HRFs) with alternative filter material". in Water SA Vol. 32 No. 1, 2006, pp.104-105.

[7] H. Blackburn, "Filter effective on surface water", www.watertechon line.com,1997, Vol. 2.

[8] J. Zeng, S. Chen, K. Wan, J. Li, D. Hu, S. Zhang and X. Yu, "Study of biological up-flow roughing filters designed for drinking water pretreatment in rural areas: using ceramic media as filter material". in Environmental technology, 2018, pp.1-10.

[9] M. Wegelin, “Surface water Treatment by Roughing Filters". Duebendorf, SANDEC,1996, pp.IV4, 5, 6, VI-6, IX-6, 8, X-5.

[10] National Drinking Water Quality Standard (NDWQS), "National Drinking Water Quality Standard, Kathmandu" in Ministry of Physical Planning and Works, 2008, pp.1.

[11] O. I. Nkwonta, O. A. Olufayo, G.M. Ochieng, J. A. Adeyemo and F.A. Otieno (2010). Turbidity removal: Gravel and charcoal as roughing filtration media. South African Journal of Science, 2010, pp. 106 (11-12), 1-5. DOI: 10.4102/sajs. v106i11/12., 196.

[12] R.C. Joshi, "Comparative Study of Gravel and Anthracite as Filter Media in Up Flow Roughing Filter”, Msc. Thesis, MSc. Programme in Environmental Engineering, Department of Civil Engineering, Pulchowk Campus, Institute of Engineering, Tribhuvan University, Kathmandu, Nepal. pp 1, 2017, pp. 24, 39

[13] World Health Organization (WHO), "Guidelines for drinking-water quality: incorporating 1st and 2nd addenda, Vol. 1" in World Health Organization (WHO), 2008. pp. 219.

[14] Y. Hashimoto, H. Takashima, and S. Jayamohan. "Application of roughing filter to pre-treat 1,000 NTU raw water for slow sand filter". in Water Practice \& Technology, 14(2), 2019, pp. 355-364. 